Supplement of Geosci. Model Dev., 11, 429-451, 2018

https://doi.org/10.5194/gmd-11-429-2018-supplement

(C) Author(s) 2018. This work is distributed under

the Creative Commons Attribution 3.0 License.

(c) (1)

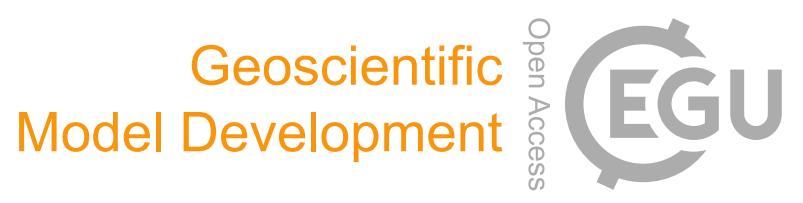

Supplement of

\title{
Modeling vegetation and carbon dynamics of managed grasslands at the global scale with LPJmL 3.6
}

Susanne Rolinski et al.

Correspondence to: Susanne Rolinski (susanne.rolinski@ pik-potsdam.de)

The copyright of individual parts of the supplement might differ from the CC BY 3.0 License. 
S1 Maps of default option $D$
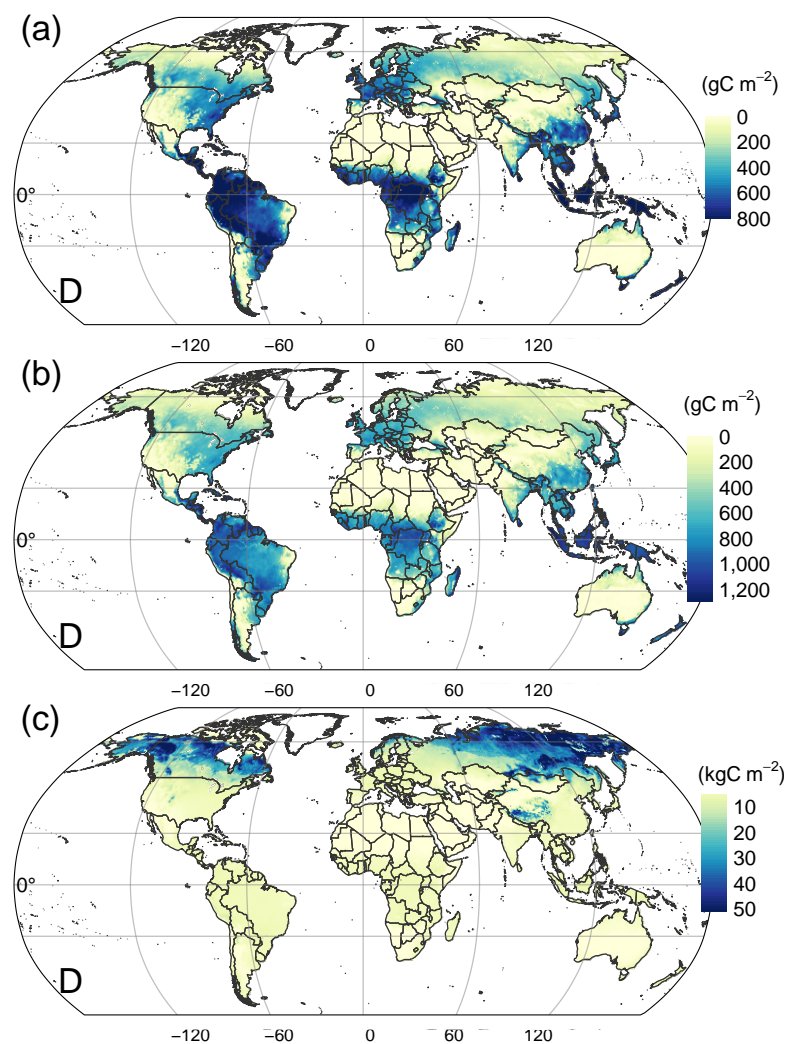

Figure S1. Simulation results for option $D$ averaged over 1998 to 2002 , a) grass harvest $\left(\mathrm{gC} \mathrm{m}^{-2}\right)$, b) NPP $\left(\mathrm{gC} \mathrm{m}^{-2}\right)$ and c) soil carbon $\left(\mathrm{kgC} \mathrm{m}^{-2}\right)$.
S2 Maps of mowing option $M$
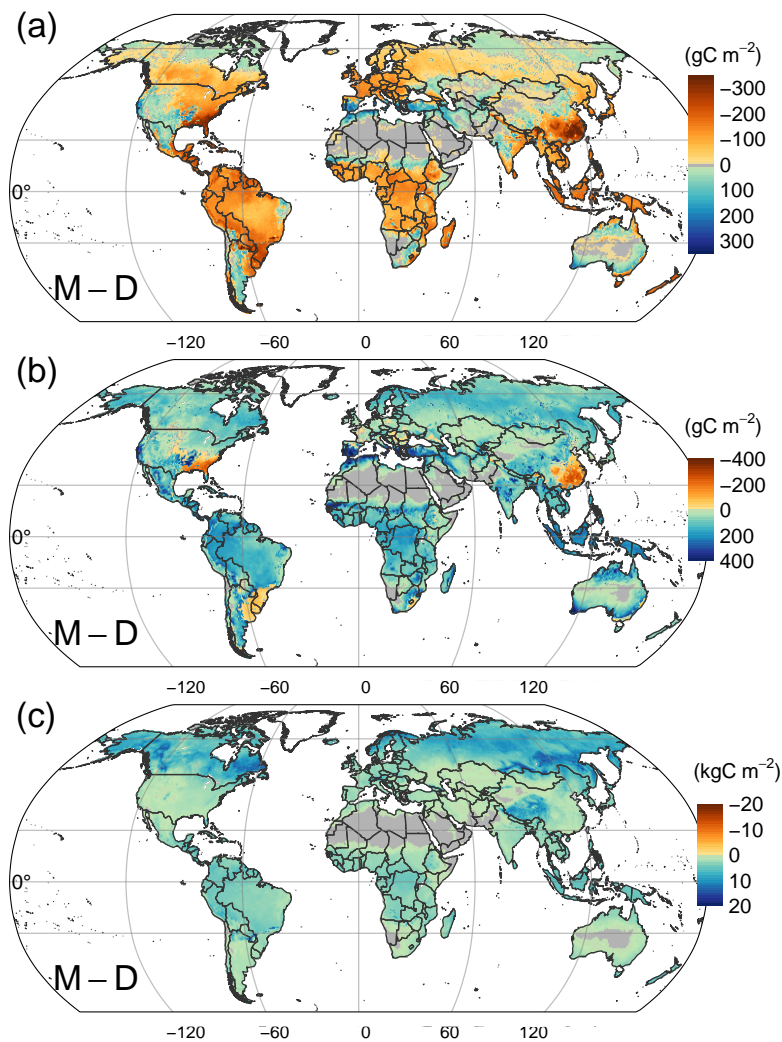

Figure S2. Simulation results for option $M$ averaged over 1998 to 2002 , a) grass harvest difference to option $D\left(\mathrm{gC} \mathrm{m}^{-2} \mathrm{a}^{-1}\right)$, b) NPP difference to option $D\left(\mathrm{gC} \mathrm{m}^{-2} \mathrm{a}^{-1}\right)$ and c) soil carbon difference to option $D\left(\mathrm{kgC} \mathrm{m}^{-2}\right)$. 
S3 Maps of daily grazing option $G_{D}$
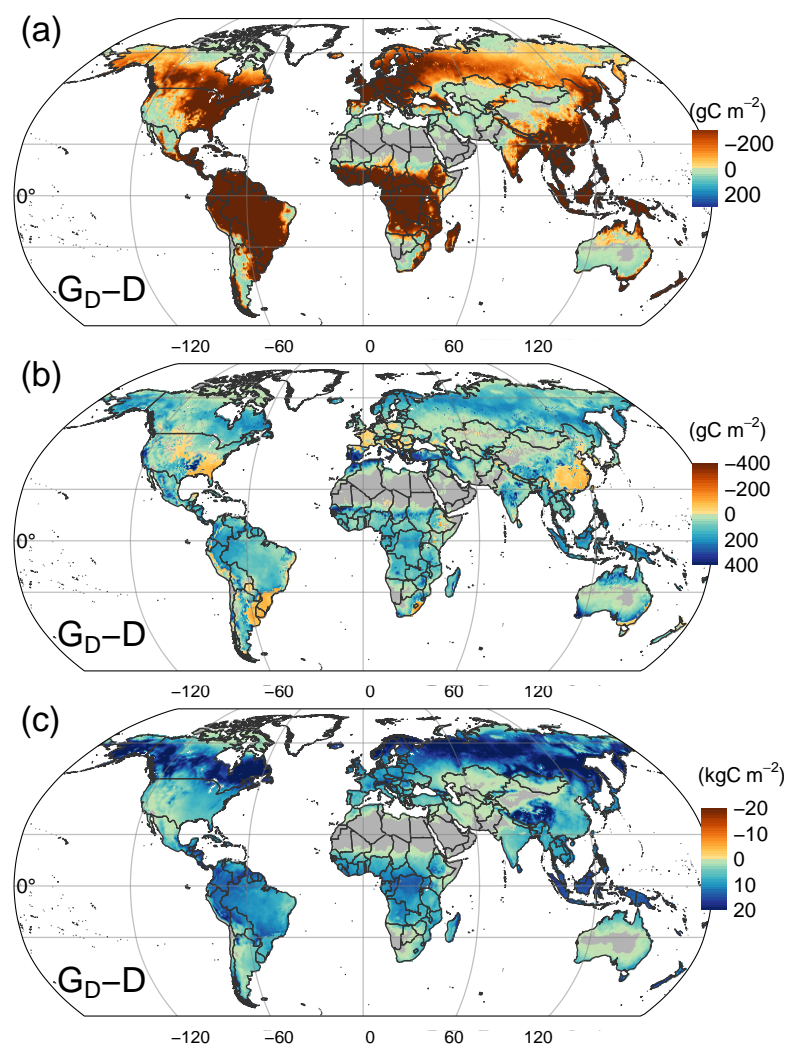

Figure S3. Simulation results for option $G_{D}$ averaged over 1998 to 2002 , a) grass harvest difference to option $D\left(\mathrm{gC} \mathrm{m}^{-2} \mathrm{a}^{-1}\right)$, b) NPP difference to option $D\left(\mathrm{gC} \mathrm{m}^{-2} \mathrm{a}^{-1}\right)$ and c) soil carbon difference to option $D\left(\mathrm{kgC} \mathrm{m}^{-2}\right)$.

\section{S4 Maps of rotational grazing option $G_{R}$}
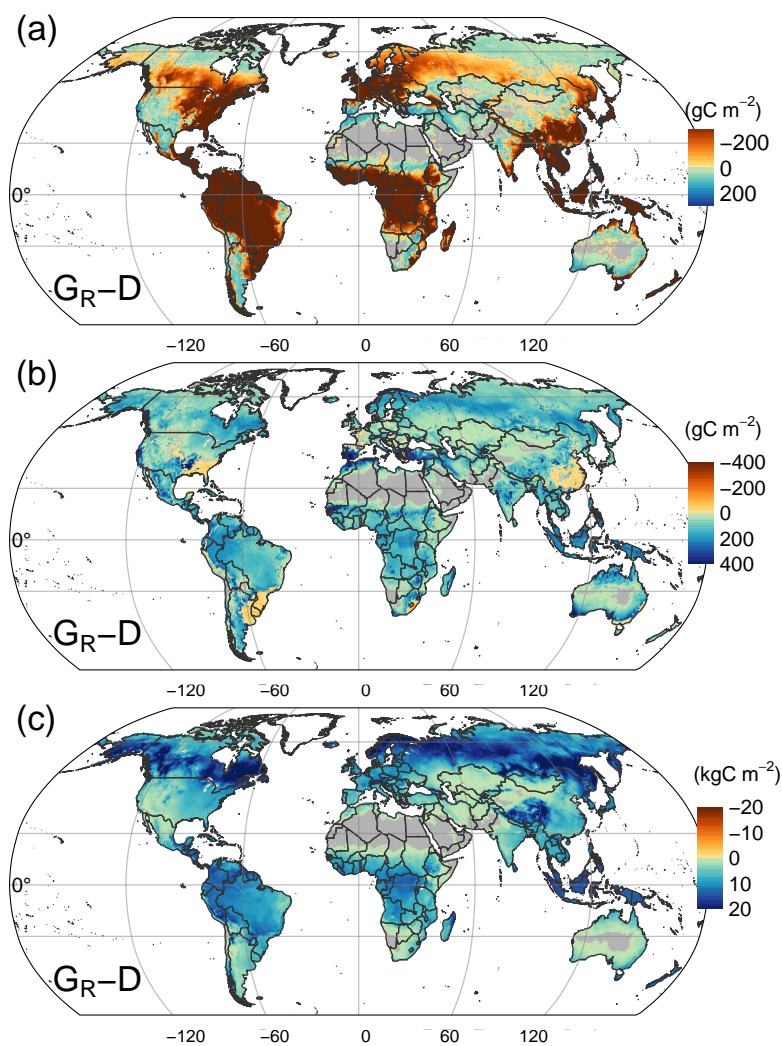

Figure S4. Simulation results for option $G_{R}$ averaged over 1998 to 2002 , a) grass harvest difference to option $D\left(\mathrm{gC} \mathrm{m}^{-2} \mathrm{a}^{-1}\right)$, b) NPP difference to option $D\left(\mathrm{gC} \mathrm{m}^{-2} \mathrm{a}^{-1}\right)$ and c) soil carbon difference to option $D\left(\mathrm{kgC} \mathrm{m}^{-2}\right)$. 